DOI: $10.25140 / 2411-5215-2020-2(22)-117-130$

Юлія Коваленко, Іван Коваль, Слизавета Близненко

\title{
ВПЛИВ МОДЕЛІ СЕКТОРУ ФІНАНСОВИХ КОРПОРАЦІЙ І РИНКУ ЦІННИХ ПАПЕРІВ НА ІНВЕСТИЦЙНН ПРОЦЕСИ В УКРАЇНІ
}

\author{
Юлия Коваленко, Иван Коваль, Елизавета Близненко
}

\section{ВЛИЯНИЕ МОДЕЛИ СЕКТОРА ФИНАНСОВЫХ КОРПОРАЦИЙ И РЫНКА ЦЕННЫХ БУМАГ НА ИНВЕСТИЦИОННЫЕ ПРОЦЕССЫ В УКРАИНЕ}

Yuliia Kovalenko, Ivan Koval, Yelyzaveta Blyznenko

\section{THE INFLUENCE OF THE SECTOR OF FINANCIAL CORPORATIONS AND SECURITIES MARKET MODEL ON INVESTMENT PROCESSES IN UKRAINE}

У межах статті визначено вплив траєкторії попереднього розвитку фінансового сектору і ринку иінних паперів на інвестиційні процеси в Украӥні. Проаналізовано функціонування фінансових установ на теренах Украӥни наприкінці XIX cm., визначено проблеми розвитку фінансового сектору в СРСР. Ідентифіковано причини поширення банкочентричної моделі фінансового сектору та ринку изіних паперів в Україні. Розглянуто етапи інституційних трансформацій у фінансовому секторі та ринку ичінних паперів в Україні. Розкрито їхній вплив на еволюиію інвестиційних процесів за допомогою визначення структури капітальних вкладень, показників фінансової глибини, активів фінансових корпорачій тощо. Акиентовано увагу на необхідності розвитку недепозитних фінансових посередників $і$ допоміжних фінансових корпорачій, щз забезпечуватиме формування комплементарної моделі фінансового сектору й ринку цінних паперів.

Ключові слова: ринок изіних паперів; фінансовий сектор; фінансові корпорації; банки; цүінні папери; інвестиції.

Рис.: 4. Табл.: 1. Бібл.: 17.

В рамках статьи определено влияние траектории предшествуюшего развития финансового сектора и рынка ценных бумаг на инвестиционные процессы в Украине. Проанализированы функционирование финансовых учреждений на территории Украины в коние ХІХ в., определены проблемы развития финансового сектора в СССР. Идентифицированы причины распространения банкоцентрической модели финансового сектора и рынка ияенных бумаг в Украине. Рассмотрены этапы институциональных трансформаций в финансовом секторе и рынке иенных бумаг в Украине. Раскрыто их влияние на эволючию инвестиционных процессов с помощью определения структуры капитальных вложений, показателей финансовой глубины, активов финансовых корпораций и т. д. Акцентировано внимание на необходимости развития недепозитных финансовых посредников и вспомогательных финансовых корпораций, обеспечивающих формирование комплементарной модели финансового сектора и рынка иенных бумаг.

Ключевые слова: рынок ценных бумаг; финансовый сектор; финансовые корпорации; банки; иенные бумаги; инвестиции

Рис.: 4. Табл.: 1. Библ.: 17.

The article identifies the impact of the trajectory of the previous development of the financial sector and the securities market on investment processes in Ukraine. The functioning of financial institutions in Ukraine at the end of the XIX century is analyzed, the problems of financial sector development in the USSR are determined. The reasons for the spread of the bank-centric model of the financial sector and the securities market in Ukraine have been identified. The stages of institutional institutional transformations in the financial sector and the securities market in Ukraine are considered. Their influence on the evolution of investment processes by determining the structure of capital investments, indicators of financial depth, assets of financial corporations, etc. is revealed. Emphasis is placed on the need to develop non-deposit financial intermediaries and subsidiary financial corporations, which will ensure the formation of a complementary model of the financial sector and the securities market.

Keywords: securities market; financial sector; financial corporations; banks; securities; investments.

Fig.: 4. Table: 1. References: 17.

JEL Classification: G23; G11; G30

Постановка проблеми. Глобалізований світ викликає потужний розвиток ринків цінних паперів і секторів фінансових корпорацій (далі - фінансових секторів), які мають забезпечувати трансформаційні процеси перетворення заощаджень в інвестиції, що становить передумови сталого розвитку. Сучасне відношення фінансових активів до ВВП (фінансова глибина) світової економіки сягає понад 400 \%. 3 одного боку, це приводить до позитивного впливу на національні економіки, а з іншого - фінансовий сектор і ринок цінних паперів спричиняють різні ризики через їх відрив від суспільних потреб, що яскраво проявилось під час світової фінансової кризи 2007-2008 pр. Висока прибутковість, що отримується в секторі фінансових корпорацій і на ринку цінних паперів, не може досягатися принесенням у жертву ефективності та процвітання решти економіки.

() Коваленко Ю. М., Коваль І. А., Близненко С. О., 2020 
Особливе значення проблематика становлення та подальшого розвитку фінансових секторів і ринків цінних паперів набула у країнах колишнього соціалістичного табору через суперечливу взаємодію нових ринкових інституцій зі старим інституційним середовищем із його неформальними нормами, що залишились від адміністративнокомандної системи у спадок. При цьому панівною є позиція, що структура фінансового сектору визначається механізмом фінансування інвестиційних процесів, а роль банківських установ на ринку цінних паперів. Сучасному стану і фінансового сектору, і ринку цінних паперів в Україні властивою $є$ незавершеність інституційних трансформацій, що призводить до гальмування подальшого економічного розвитку та реалізації різних стратегічних проєктів і програм. У цьому сенсі всі інвестиційні процеси в економіці залежатимуть від траєкторій попереднього функціонування та розвитку фінансового сектору й ринку цінних паперів.

Аналіз останніх досліджень і публікацій. Дослідження проблем розвитку сектору фінансових корпорацій (фінансового сектору) та ринку цінних паперів перебувають у центрі уваги західних учених-економістів, зокрема П. Бернстайна, 3. Боді, Дж. Ван Хорна, Р. Габбарда, А. Деміргуч-Кунт, Ф. Додда, Л. Зінгалеза, Дж. Кейнса, Р. Колба, Р. Левіна, Х. Мінські, Ф. Мишкіна, Р. Мертона, Р. Раджана, Р. Родрігеса, Л. Росса, Дж. Сакса, П. Самуельсона, Дж. Сороса та інших. При цьому практичні напрацювання, що розраховані на інші країни, не можуть бути застосовані повною мірою в національних економіках. Адаптація зарубіжних розробок до специфіки національних фінансових процесів, зокрема в Україні, викликає суттєвий науково-практичний інтерес, а також потребує спеціального дослідження. На нашу думку, цікавити $є$ наукові дослідження українських учених у сфері інвестицій, ринку цінних паперів і фінансового сектору, таких як Л. Алексеєнко, О. Барановський, Я. Белінська, О. Береславська, Т. Васильєва, О. Вовчак, О. Гаманкова, В. Геєць, В. Зимовець, С. Сгоричева, С. Козьменко, В. Козюк, В. Корнєєв, М. Крупка, С. Леонов, І. Лютий, Т. Майорова, В. Міщенко, С. Міщенко, О. Мозговий, А. Мороз, С. Науменкова, С. Онишко, В. Опарін, А. Пересада, О. Петрук, Л. Примостка, Н. Ткаченко, В. Федосов, І. Школьник та ін.

Виділення недосліджених частин загальної проблеми. Визнаючи цінність наукових розробок учених України та інших країн, їхній вагомий внесок у розвиток теорії фінансів та інвестицій, нинішній стан наукової розробки цієї проблеми завершеним вважати не можна. Це можна пов'язати, з одного боку, з процесами глобалізації, фінансіалізації практично всіх економічних процесів, розгортанням кризових явищ і відповідним пошуком оптимальних способів нівелювання їхні дії, а з іншого - певною фрагментарністю в наукових підходах до розуміння моделі фінансового сектору та ринку цінних паперів, їхньої ролі в інвестиційних процесах, а також неоднозначним поглядом на їх функціонування та подальший розвиток. Це поглиблює науково-методологічні й методичні проблеми, що безпосередньо позначається на фінансовій та страховій діяльності, а в підсумку впливає на сучасні інвестиційні процеси.

Головною метою цієї роботи $\epsilon$ висвітлення еволюції розвитку фінансового сектору (сектору фінансових корпорацій) і ринку цінних паперів в Україні, їхньої ролі у фінансуванні інвестиційних процесів.

Виклад основного матеріалу. Дореволюційна фінансова політика Російської імперії використовувала досвід Німеччини, адже центр спекулятивних операцій із цінними паперами і кредитними грошима становила Берлінська біржа. На той час Німеччина стала основним зовнішньоторговельним партнером, а сам Берлін - фінансовим і торговельним центром як найближчий до західних кордонів. У Російській імперії державні боргові зобов'язання розміщувались переважно при посередництві німецьких банків на ринку грошей Німеччини. Уже в цей період проявились відмінності у німецькій моделі 
ФІНАНСОВІ РЕСУРСИ: ПРОБЛЕМИ ФОРМУВАННЯ ТА ВИКОРИСТАННЯ

фінансування підприємств порівняно із англо-американською, адже «чим далі країна знаходиться від Великобританії, тим більше банки (і уряд) заміщували ініціативи незалежних підприємців... особливо тісний взаємозв'язок існував між крупними банками та промисловими компаніями - взаємовідносини, що дуже відрізнялись від них у Великобританії та Франції» [15, с. 129-130].

Як підсумок, унаслідок економічної реформи 1850-1860 років на теренах України стали розвиватись депозитні фінансові посередники, що були представлені: 22 відділеннями Державного банку, близько 87 філіями трьох головних акціонерних комерційних банків Російської імперії (Петербурзьким міжнародним, Азовсько-Донським, Російським торговельно-промисловим); українськими - 6 акціонерними, 2 приватними та 2 казенними іпотечними банками, 10 акціонерними комерційними банками, 70 міськими громадськими банками, 911 ощадно-кредитними асоціаціями, 2181 кредитним товариством, 5 кооперативними банками, 5 кредитними централями, 4 ломбардами, 100 казначействами, 8 приватними банківськими конторами. Друга половина XIX ст. відзначилась розвитком вже дисконтних контор, що придбавали боргові цінні папери для їх подальшої реалізації на ринках капіталу, а також контрактових ярмарків, де укладалися угоди між власниками і позичальниками капіталів. На початку XX ст. депозитні фінансові установи функціонували у 350 населених пунктах, що були розташовані на сучасній території України [6, с. 425]. Отже, на той час існував широко диверсифікований фінансовий сектор із переважанням банківських установ. «До Першої світової війни (1914-1918рр.) на території підросійської України працювало 3660 кредитних установ різного типу. Серед них було 161 відділення акціонерних банків і банківських контор та 316 товариств взаємного кредиту, а загалом у межах українських губерній діяло 477 кредитних фірм» [3, с. 35].

«Щодо недепозитних фінансових посередників, то й вони також набували свого розвитку. Для прикладу, у Феодосії у 1812 р. було утворено перше страхове товариство, а наприкінці XIX ст. вони були представлені вже 13 акціонерними товариствами (страхові захисти від пожеж), 34 товариствами земського страхування, 9 міськими товариствами взаємного страхування від вогню, 2 товариствами взаємного страхування життя, 3 товариствами взаємного морського страхування, а також філіями провідних страховиків США, Великобританії, Франції, Німеччини та Російської імперії» [6, с. 425-426]. Сформувалась система соціального страхування та недержавного пенсійного забезпечення завдяки створенню приватних товариств взаємного страхування, страхових кас, а також пенсійних фондів. С. Мошенський відзначив, що, «за даними перепису населення на 1897 р. у сфері фінансових послуг працювало у: Петербурзі 2890 (0,2 \% населення); Москві - 2078 (0,2 \%), Одесі - 426 (0,1 \%); Києві - 619 (0,25\%); Харкові - 332 осіб $(0,2 \%) »[10$, c. 354$]$.

Наприкінці 1860-х - початку 1870-х рр. бурхливо розвивається ринок цінних паперів, зокрема за ажіотажної організації акціонерних товариств завдяки «Грюндерському буму» у Німеччині, де активізувався випуск і продаж цінних паперів, переважно акцій. У 1873 р. в Англії поширився «Грюндерський крах», який потім перекинувся на Німеччину і спровокував світову фінансову кризу на близько двадцять років. У цей самий час серед населення формується середній клас, який дав поштовх індивідуальному інвестуванню. На початок XX ст. на теренах України було організовано діяльність 11 фондових бірж, де відбувалась торгівля державними борговими цінними паперами, простими і привілейованими акціями, корпоративними облігаціями, а основними учасниками торгів виступали страхові компанії та банки.

Зі створенням СРСР розвиток фінансових установ визначався органічним вбудовуванням відносно неефективної та фрагментарної системи державних фінансових інститутів в адміністративно-командну економічну модель 3 відсутністю фінансового ринку 
як такого, а також його елементів (табл. 1). Консолідація та розподіл фінансових ресурсів здійснювались через бюджетну систему і державні банки, що відігравали роль фінансових управлінь і рахункових палат. Вони пасивно реалізовували фінансові операції та залучали кошти на депозити згідно з централізованими кредитними планами в межах передбачених для нефінансових установ бюджетів лімітів. Були відсутні недепозитні фінансові посередники, за виключенням Держстраху, а також ринок цінних паперів та економічна свобода товаровиробників, ліквідовано приватну власність.

Таблиця 1

\section{Етапи інституиійних трансформацій у фінансовому секторі} та на ринку цінних паперів в Украӥні

\begin{tabular}{|c|c|c|c|c|c|}
\hline \multirow[b]{2}{*}{ Риси } & \multicolumn{5}{|c|}{ Етапи } \\
\hline & $\begin{array}{c}\text { Визначаль- } \\
\text { ний } \\
(1920- \\
1987 \text { рр. }) \\
\text { Адміністра- } \\
\text { тивно- } \\
\text { командна } \\
\text { економіка }\end{array}$ & $\begin{array}{c}\text { Стартовий } \\
(1988- \\
1995 \text { рр. }) \\
\text { Формування } \\
\text { ринкового } \\
\text { механізму }\end{array}$ & $\begin{array}{c}\text { Накопичення } \\
\text { (1996 - } \\
1999 \text { рр.) } \\
\text { Формування } \\
\text { ринково } \\
\text { орієнтованої } \\
\text { взаємодії }\end{array}$ & $\begin{array}{c}\text { Забезпечення } \\
\text { та контроль } \\
\text { (2000 р. - пер- } \\
\text { ша половина } \\
2008 \text { р.) } \\
\text { Формування } \\
\text { інноваційно } \\
\text { активної } \\
\text { взаємодії } \\
\end{array}$ & $\begin{array}{c}\text { Модернізація } \\
\text { та стійкість } \\
\text { (друга поло- } \\
\text { вина } \\
2008 \text { р. - } \\
\text { дотепер) } \\
\text { Забезпечення } \\
\text { фінансової } \\
\text { безпеки } \\
\end{array}$ \\
\hline $\begin{array}{l}\text { Оцінка фінансових } \\
\text { та інвестиційних } \\
\text { ризиків }\end{array}$ & Відсутня & Формується & $\begin{array}{c}\text { Усвідомлюється } \\
\text { більшістю } \\
\text { суб'єктів ринку }\end{array}$ & $\begin{array}{c}\text { Стає нормою } \\
\text { фінансової дія- } \\
\text { льності }\end{array}$ & $\begin{array}{l}\text { Пруденцій- } \\
\text { ний нагляд. } \\
\text { Регулюється } \\
\end{array}$ \\
\hline $\begin{array}{l}\text { Участь фінансових } \\
\text { установ в опосере- } \\
\text { дкуванні } \\
\text { грошових потоків } 3 \\
\text { підвищеним ризи- } \\
\text { ком }\end{array}$ & Відсутня & $\begin{array}{c}\text { Активізується } \\
\text { зі зростанням } \\
\text { державного } \\
\text { внутрішнього } \\
\text { боргу }\end{array}$ & $\begin{array}{c}\text { Максимізується у } \\
1998 \text { р. }\end{array}$ & $\begin{array}{c}\text { Знижується } \\
\text { внаслідок по- } \\
\text { ширення прак- } \\
\text { тики обмеження } \\
\text { інфляції }\end{array}$ & $\begin{array}{l}\text { Обмежується } \\
\text { регуляторни- } \\
\text { ми і наглядо- } \\
\text { вими органа- } \\
\text { ми }\end{array}$ \\
\hline $\begin{array}{l}\text { Міжсекторна взає- } \\
\text { модія і спрямова- } \\
\text { ність фінансових } \\
\text { потоків }\end{array}$ & $\begin{array}{l}\text { Розподіл за } \\
\text { планами та } \\
\text { завданнями }\end{array}$ & $\begin{array}{l}\text { Участь у про- } \\
\text { цесах перероз- } \\
\text { поділу держа- } \\
\text { вної власності } \\
\text { на біржах }\end{array}$ & $\begin{array}{c}\text { Акумуляція осно- } \\
\text { вних фінансових } \\
\text { потоків у нефіна- } \\
\text { нсових корпора- } \\
\text { ціях } \\
\end{array}$ & $\begin{array}{c}\text { Переорієнтація } \\
\text { фінансових по- } \\
\text { токів на спожи- } \\
\text { вче кредиту- } \\
\text { вання }\end{array}$ & $\begin{array}{c}\text { Активізація } \\
\text { інвестиційних } \\
\text { процесів та } \\
\text { інвестиційної } \\
\text { діяльності }\end{array}$ \\
\hline $\begin{array}{l}\text { Напрями фінансо- } \\
\text { вого інвестування } \\
\text { як індикатор довіри } \\
\text { до фінансових кор- } \\
\text { порацій }\end{array}$ & $\begin{array}{c}\text { Масові зао- } \\
\text { щадження в } \\
\text { Ощадному } \\
\text { банку, висо- } \\
\text { кий ступінь } \\
\text { безпеки та } \\
\text { ліквідності }\end{array}$ & $\begin{array}{c}\text { Зростання за- } \\
\text { ощаджень на- } \\
\text { селення у де- } \\
\text { позитах, } \\
\text { вкладення у } \\
\text { ЦП, зниження } \\
\text { рівня правово- } \\
\text { го захисту та } \\
\text { ліквідності } \\
\end{array}$ & $\begin{array}{c}\text { Висока частка } \\
\text { готівки, низький } \\
\text { рівень вкладень у } \\
\text { депозити та цінні } \\
\text { папери, форму- } \\
\text { вання систем га- } \\
\text { рантій збережен- } \\
\text { ня заощаджень }\end{array}$ & $\begin{array}{c}\text { Збільшення } \\
\text { вкладень } \\
\text { у фінансові } \\
\text { інструменти, } \\
\text { зниження рівня } \\
\text { гарантування } \\
\text { повернення } \\
\text { коштів і } \\
\text { ліквідності } \\
\end{array}$ & $\begin{array}{c}\text { Гарантування } \\
\text { інвестицій та } \\
\text { розвиток сис- } \\
\text { теми захисту } \\
\text { прав спожи- } \\
\text { вачів фінан- } \\
\text { сових послуг }\end{array}$ \\
\hline $\begin{array}{l}\text { Створення новітніх } \\
\text { способів акумуля- } \\
\text { ції грошових } \\
\text { ресурсів }\end{array}$ & Відсутнє & $\begin{array}{c}\text { Порушення } \\
\text { договірних } \\
\text { зобов'язань із } \\
\text { залучення } \\
\text { грошових ре-- } \\
\text { сурсів задля } \\
\text { отримання } \\
\text { прибутків }\end{array}$ & $\begin{array}{c}\text { Ускладнення } \\
\text { впровадження } \\
\text { новітніх способів } \\
\text { залучення грошо- } \\
\text { вих ресурсів че- } \\
\text { рез низький рі- } \\
\text { вень довіри до } \\
\text { фінансових уста- } \\
\text { нов }\end{array}$ & $\begin{array}{c}\text { Інтеграція фі- } \\
\text { нансових уста- } \\
\text { нов з викорис- } \\
\text { танням } \\
\text { фінансового } \\
\text { інжинірингу, } \\
\text { розширення } \\
\text { сфери роздріб- } \\
\text { них фінансових } \\
\text { послуг }\end{array}$ & $\begin{array}{c}\text { Розвиток фі- } \\
\text { нансового } \\
\text { сервісу та } \\
\text { підвищення } \\
\text { якості фінан- } \\
\text { сових проду- } \\
\text { ктів }\end{array}$ \\
\hline
\end{tabular}

Джерело: складено на основі [6; 5]. 
ФІНАНСОВІ РЕСУРСИ: ПРОБЛЕМИ ФОРМУВАННЯ ТА ВИКОРИСТАННЯ

Отже, не дивно, що ринкові трансформації 90-х рр. в Україні, як і в Російській Федерації, привели до того, що фінансовий сектор і ринок цінних паперів повторили основні риси їхнього дореволюційного розвитку з: а) переважанням депозитних посередників; б) борговим характером i незначною роллю пайових фінансових інструментів; в) посиленим державним регулюванням і значною часткою державних цінних паперів; г) виконанням банками операцій з андерайтингу, тобто розміщенням цінних паперів на первинному ринку, комісійними операціями з ними, інвестуванням в акціонерні капітали підприємств власних коштів. Як відзначав ще у 1913 р. російський вчений М. Боголєпов, «історично наші фондові біржі є органами банків... Самостійні російські емісії можливі тільки за безпосередньої участі банків» [2, с. 380]. Натомість формування ринку цінних паперів, що ледь-ледь набував свого розвитку, було визначено реалізувати через американську, або ринкову, модель (де власність $є$ більш диверсифікованою порівняно з іншими країнами). Доводилось, що у 90-і pр. саме ця модель є такою, що може забезпечити найуспішніший розвиток ринків капіталу. При цьому американські інвестори були лідерами серед світових інвесторів, а експерти із США виступили консультантами в українських реформах, зокрема у сфері формування ринкової економіки та приватизації.

Звернення до думок практиків на той період показує колізії щодо вибору тієї чи іншої моделі ринку цінних паперів. Наприклад, президент інвестиційної компанії «Кінто» С. Оксанич зазначає: «УФБ до вподоби французька модель фондового ринку. Банки пропонують прийняти німецьку, де саме банкам належить домінуюча роль. Я особисто - за американську модель, де банки дещо дистанційовані від фондового ринку. Так, у Сполучених Штатах банки працюють на фондовому ринку, але через свої дочірні підприємства. I це, передусім, забезпечує стабільність самої банківської системи» [14, с. 89].

Варто зазначити, що формування та розвиток відповідної моделі фінансового сектору та ринку цінних паперів великою мірою впливають на інвестиційну діяльність та джерела інвестиційних ресурсів. В Україні у 1996-1999 рр., тобто на етапі накопичення (табл. 1), вкладення в основний капітал здійснювалось здебільшого за рахунок власних коштів підприємств і організацій (рис. 1). У 90-х рр. банківські кредити та емісії цінних паперів увійшли в «інші джерела фінансування» і, як свідчать дані, вони становили дуже незначну частку інвестицій в основний капітал: у 1997 р. - 3,7 \%, а у 1999 р. - 7,8 \% відповідно. Натомість кредитні і депозитні ставки залишались довгий час у світі одними із найвищих. Наприкінці 1999 р. ставка рефінансування НБУ сягала 45 \%, що не відповідало нормі прибутковості реального сектору, а рівень монетизації - 17,6 \% (для порівняння, середній показник розвинених країн - 60-70 \%).

У досліджуваний період грошові ресурси спрямовувались на кредитування сектору загальнодержавного управління, частка якого перевищувала кредитування економіки. У 1995 р. співвідношення між ними сягало 4,7:5,3, а у 1999 р. сягнуло максимуму і становило вже 6,1:3,9. При цьому «гіперболізація ринку ОВДП створила проблеми управління ним та підтримки стабільності, що особливо виявилось у період фінансових криз 19971998 рр.» [9, с. 23]. У 1997 р. банківські установи мали облігацій внутрішньої державної позики на суму більше 2 млрд грн, а кредитів реальному сектору - 5,6 млрд грн. 


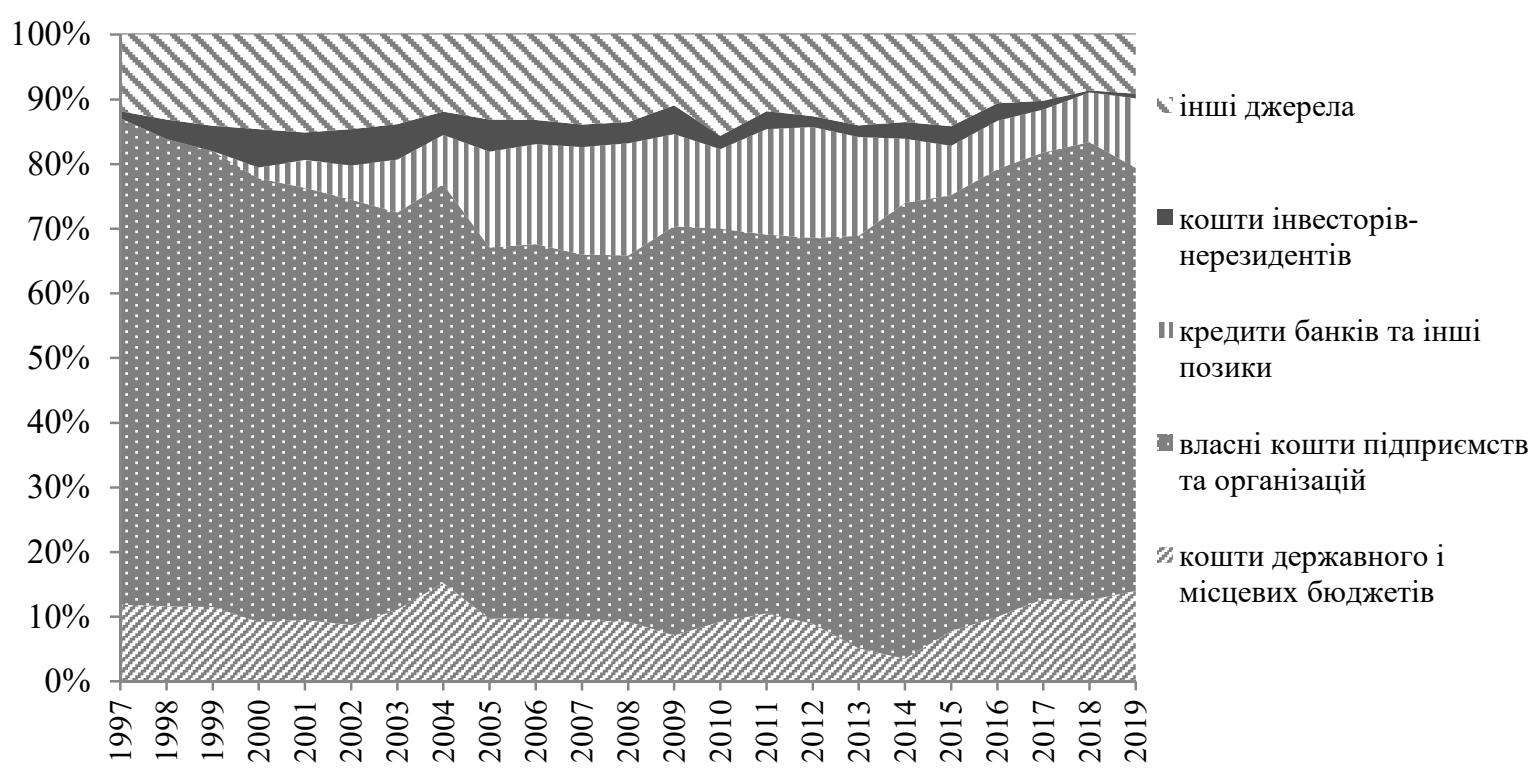

Рис. 1. Структура капітальних інвестицій за джерелами фінансування в Украӥні у 1997-2019 рр., \%

Джерело: розраховано та побудовано за даними [4].

У країні існувала невідкладна потреба в радикальних економічних проєктах і програмах, різних стратегіях, проте вплив на цей процес функціонуючих на той час фінансових установ був невеликим. Природно, що розвиток фінансового сектору та ринку цінних паперів забезпечувався банківськими установами. Активи недепозитних фінансових посередників залишались все ще незначними у порівнянні $з$ депозитними. Свою негативну роль відіграли відсутність регулятора та кардинальної реформи у сфері їх функціонування та подальшого розвитку. Натомість Словенія, Угорщина, Польща, Чехія, Словаччина та країни Балтії їх реалізували вже до 1994 р. У високорозвинених країнах активи цих фінансових установ перевищували $60 \%$ до ВВП, а у більш розвинених країнах колишнього соціалістичного табору - близько $12 \%$.

Якій моделі фінансового сектору та ринку цінних паперів сьогодні слідувати Україні? Як правильно зауважує А. Олєйнік [13], світовий ринок інститутів пропонує вибір. Наприклад, завжди можна звернутись до німецької моделі у випадку, коли не виправдовує свої сподівання побудована за принципами американського банківського права банківська система. Крім цього, відсутність специфікованих прав власності на відповідні інституційні моделі зводить витрати на їх відтворення до мінімуму. Світове право, а також право окремих країн не містить положень, які б перешкоджали запозиченню або копіюванню тих чи інших формальних правил, причому з уникненням компенсаційної виплати державам, яким належить авторство створення таких зразків.

Не новою є думка експертів: країнам, що розвиваються, рекомендується розвивати фінансовий сектор і ринок цінних паперів, що подібні до високорозвинених країн. Отже, американський фінансовий сектор із високою активністю ринку цінних паперів сприймається кращою моделлю. 32000 р. в Україні була зроблена спроба відтворення саме цієї моделі з певним розділенням кредитно-депозитної та інвестиційної банківської діяльності. Проте у США зазначене розділення припиняється, насамперед як наслідок світової фінансової кризи 2007-2008 рр., де найбільш негативну роль відіграли саме інвестиційні банки, які активно займались спекулятивними операціями. Основним нинішнім завданням Комісії з цінних паперів США (SEC) є забезпечення банківським i небанківським фінансовим посередникам рівних конкурентних та ринкових умов, а також посилення регулювання та нагляду, що забезпечує належний захист вкладників, інвесторів і підтримання ефективності ринку цінних паперів. 
ФІНАНСОВІ РЕСУРСИ: ПРОБЛЕМИ ФОРМУВАННЯ ТА ВИКОРИСТАННЯ

Відповіддю на питання щодо вибору моделі фінансування економіки стало дослідження китайських колег «Фінансова структура в економічному розвитку» [16], які довели, що оптимальна побудова фінансових секторів у країнах, що розвиваються, буде системно відрізнятись від запропонованих варіантів. Копіювання чужого досвіду не приведе до підвищення ефективності функціонування національного фінансового сектору, а також покращення його економічних показників. Натомість воно може призвести до таких руйнівних та негативних наслідків, як фінансові кризи. Наголошується, що вибір моделі та структуризації фінансового сектору залежатиме від фази економічного циклу та стадії економічного розвитку країни.

У більшості досліджень фінансового сектору та ринку цінних паперів акцентується на позитивних і негативних рисах його моделей, проте в них часто не беруться до уваги характеристики реального сектору з його нефінансовими корпораціями, що не дозволяє дати оцінку відносній ефективності альтернативної моделі на різних етапах розвитку економіки країни. Змінювана з часом структура факторів виробництва визначатиме потенціал їхнього розвитку та оптимальну структуру промисловості. Підприємства різних видів економічної діяльності мають різні ризики та обсяги. Це означає, що попит на інвестиційні та фінансові послуги залежатиме від структури виробничого капіталу підприємства і специфіки його діяльності. Тобто країни, що відрізняються різними стадіями економічного розвитку й мають відмінності в галузевій і технологічній структурі, не можуть мати структуру сектору нефінансових корпорацій і сектору фінансових корпорацій, які будуть прийнятними для всіх країн. Однак існують конкретні моделі, які будуть прийнятними на якомусь етапі економічного розвитку країни.

В українській економіці зростання капітальних інвестицій забезпечується за рахунок ендогенної пропозиції грошей (рис. 1). Так, частка банківських та інших позик зросла за 2000-2008 рр. 31,7 до 17,3\%, тобто майже у 10 разів, а у 2019 р. становила 10,8 \%. Швидкі темпи нарощування банківських операцій забезпечувались розширенням посередницької діяльності банків, що проявилось як зростання попиту інших суб'єктів економіки на позичкові ресурси. Проте бум кредитування був пов'язаний переважно з наданням незабезпечених кредитів і валютизацією, зниженням вимог до позичальників, а у підсумку - послаблення ризик-менеджменту та зростання ризиків.

У посткризовий період відновились інвестиції в реальний сектор, однак основне джерело інвестиційних ресурсів - це власні кошти підприємств і організацій, причому 3 тенденцією до зменшення їхньої питомої ваги за 2002-2012 pр. з 65,8 до 59,7 \%. Частка кредитів банків та інших позик скоротилась за 2008-2019 pр. із 17,3 до 10,8 \%. Структура кредитів нефінансовим корпораціям показує, що тут переважало кредитування торгівлі та операцій із нерухомим майном, оренди, інжинірингу та надання послуг підприємцям, що становило 52,2 \%, а промисловості - 26,9\%.

Низьке зростання інвестиційної активності в економіці за рахунок банківського кредитування зумовлене низкою причин: 1) спрямування довгострокових кредитних ресурсів на проведення фінансових операцій, зокрема, злиття і поглинання; 2) високий рівень кредитних ставок через існуючу систему кредитування суб'єктів економіки, динаміку макроекономічних показників, ризики країни у веденні бізнесу, повільний вихід української і світової економіки з кризи; 3) дисбаланси в галузевій структурі портфеля заборгованості підприємств; залучення більш вигідних ресурсів останніми через емісію цінних паперів або кредити іноземних банків; 4) ефект бухгалтерського обліку: кредити на строк більше трьох років часто враховуються як короткострокові у рамках укладених довгострокових договорів про кредитні лінії; 5) пріоритетність кредитування поточної виробничої діяльності. Як не дивно, максимальну заборгованість за кредитами вітчизняних банків мають підприємства, які мінімально використовують цей ресурс для фінансування своїх проєктів, і навпаки. 
Рисунок 2 наочно засвідчує, що в Україні за 2000-2012 рр. відбулись процеси відриву фінансового сектору від реальних економічних процесів через збільшення внутрішніх кредитів депозитних корпорацій з 23,8 до 48,7\% до ВВП, зниження ринкової капіталізації лістингових емітентів - 36 до 3,4 \%, а також несуттєвому зростанні інвестицій в основний капітал з 13,9 до 15,7 \%. Якщо у 2001 р. активи фінансових інститутів були меншими за ВВП у 2 рази, то вже у 2015 р. вони перевищили останній вже у 1,5 раза. Натомість з 2018 р. спостерігається протилежна ситуація (рис. 3). Темпи зростання ринку цінних паперів у 2013 р. перевищили ВВП, зокрема обсяг торгів на ринку перевищив цей показник на 222 млрд грн. Рисунок 4 наочно свідчить, що серед випущених цінних паперів знову переважає емісія акцій $(44,7 \%)$, збільшується боргове фінансування за рахунок облігацій (31\%).

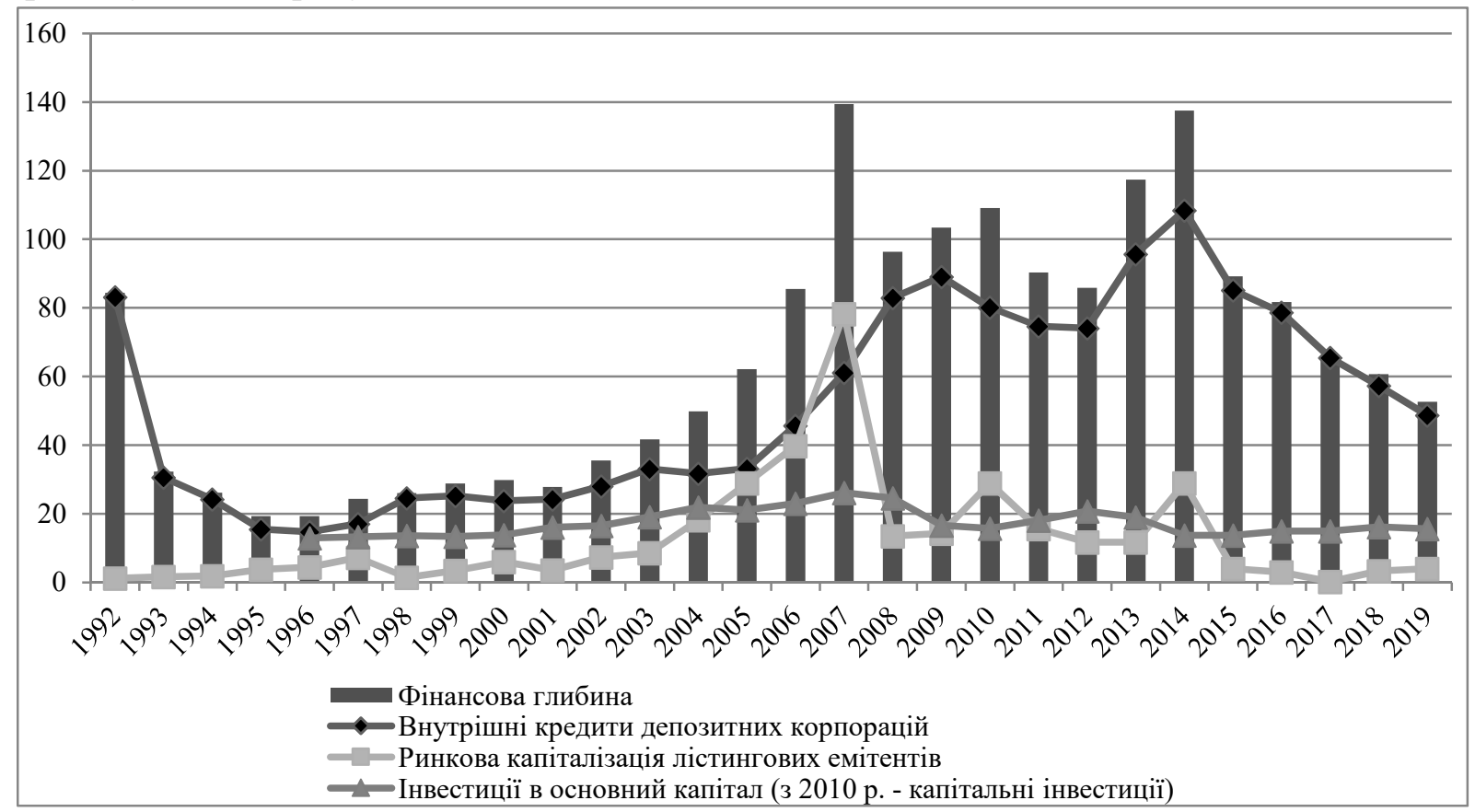

Рис. 2. Фінансова глибина економіки та інвестичї в основний капітал (капітальні інвестиції) в Україні у 1992-2019 рр.,\% до ВВП

Джерело: розраховано та побудовано за даними $[4 ; 17]$.

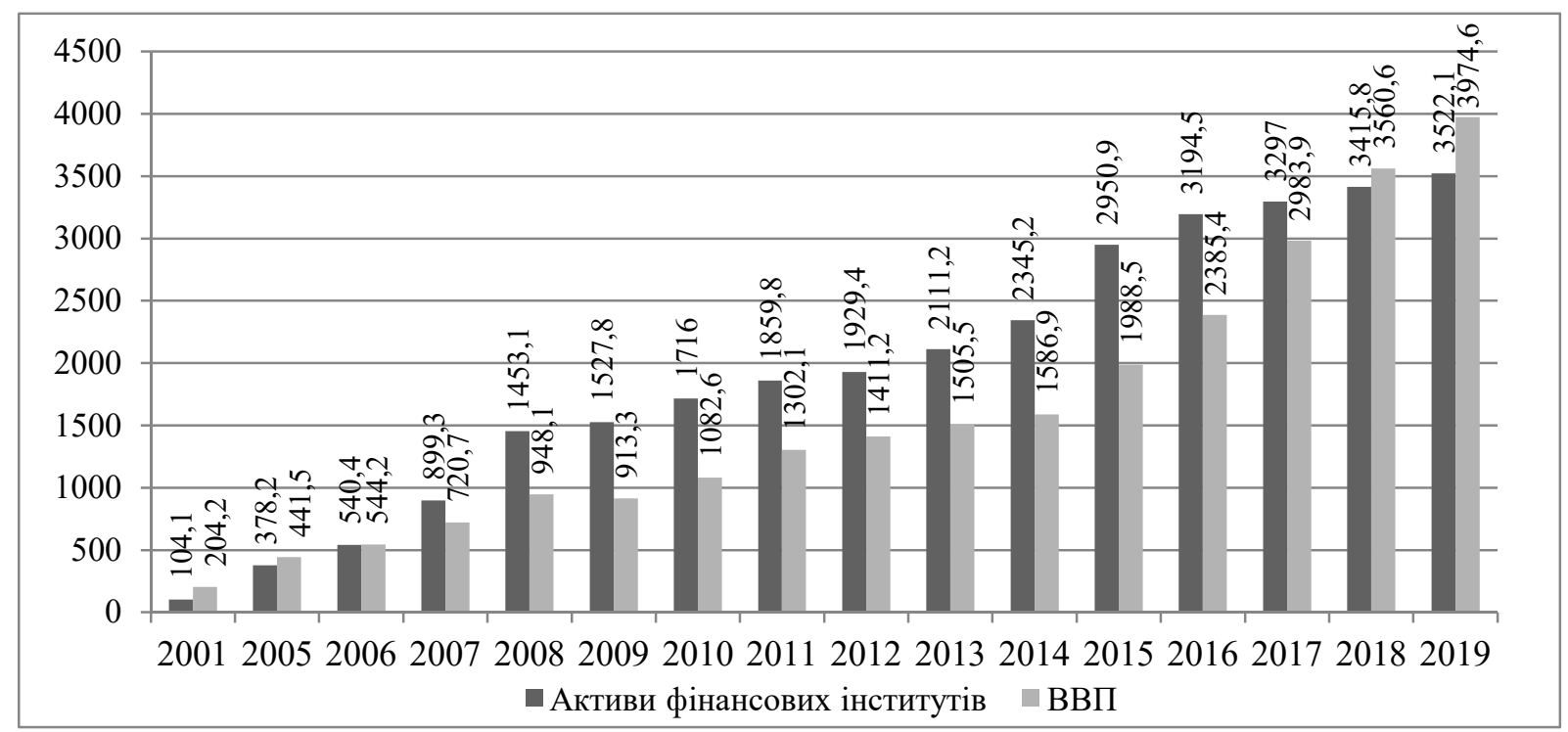

Рис. 3. Обсяги ВВП і активів фінансових корпорацій в Україні у 2001-2019 рр., млрд грн Джерело: побудовано за даними [4; 12]. 
ФІНАНСОВІ РЕСУРСИ: ПРОБЛЕМИ ФОРМУВАННЯ ТА ВИКОРИСТАННЯ

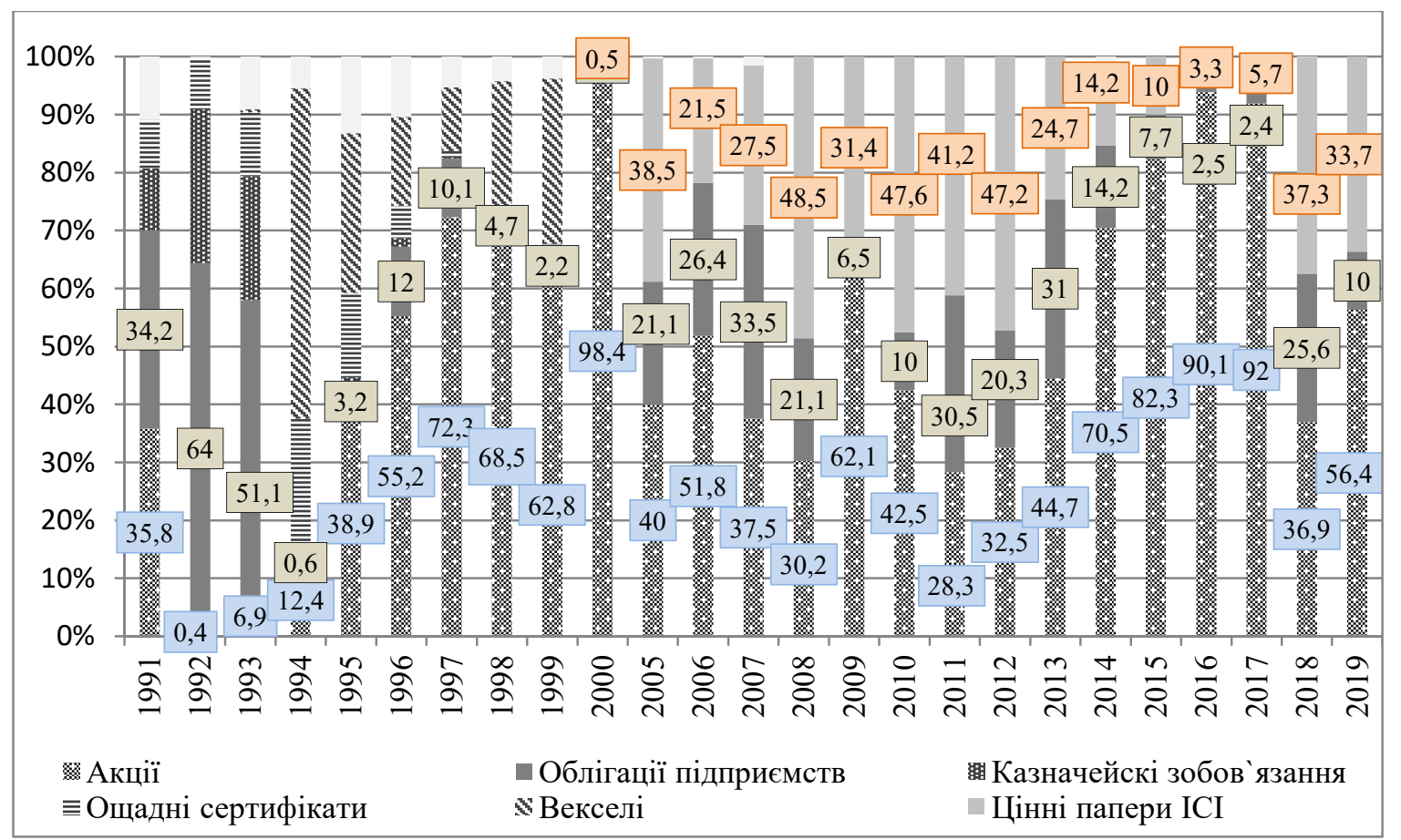

Рис. 4. Структура випущених цінних паперів в Україні у 1991-2019 рр., \%

Джерело: розраховано і побудовано за даними [11].

Окремо слід наголосити на склад фінансових активів фінансових корпорацій загалом. Так, намітилась тенденція до вкладення фінансових ресурсів у цінні папери (зокрема акції та інші форми участі в капіталі): за 2008-2019 pp. їх обсяг збільшився практично вдвічі. Природно, найбільшими інвесторами є банки, портфель цінних паперів яких переважно складається 3 державних облігацій. Наразі страхові резерви у цінних паперах у 2019 р. на 32,3 \% складались 3 акцій (8,4\%), державних цінних паперів $(21,6 \%)$, облігацій $(2,1 \%)$ та іпотечних цінних паперів $(0,1 \%)$. Через нормативні обмеження НПФ і ICI мають менш збалансовані портфелі порівняно з банками. Розвиток ринку цінних паперів не стимулює переважання у активах ICI депозитів, дебіторської заборгованості і нерухомості. Такі чинники, як дефіцит надійних фінансових інструментів, різнорідні з боку регуляторів вимоги до складу активів не дають змоги фінансовим посередникам як інституційним інвесторам стати впливовими гравцями ринку капіталу та консолідувати ресурси для економічного розвиту.

Натомість кредити в активах фінансових корпорацій збільшились несуттєво. Основна частина довгострокового кредитування (понад 5 років) надається домогосподарствам (35,6 \% у 2008 р.), тоді як нефінансовим корпораціям - 9,8 \%. У посткризовий період ситуація дещо змінилась: у 2019 р. їх частка становила 15,2 і 9,4 \% відповідно. Позички для бізнесу (понад 5 років) надаються під 10\% \% річних. При цьому між кредитними ставками і інфляцією простежується слабкий зв'язок, а найважче отримати кредит восени i взимку, коли банками переважно втрачається гривнева ліквідність і переглядаються умови для позичальників. 3 іншого боку, підприємства реального сектору «закредитовані», тобто мають набагато більше заборгованості, ніж такі структури в інших країнах.

Серед вітчизняних науковців [1] поширеною є думка, що головною проблемою збільшення кредитних ресурсів, спрямованих у реальний сектор економіки для забезпечення інвестиційно-інноваційної діяльності, $є$ низька капіталізація банківської системи України, а також структура пасивів більшості банків, у яких переважають короткострокові ресурси, що не дає змоги повною мірою забезпечувати інноваційну сферу належним обсягом фінансових ресурсів. Однак статистичні дані суперечать цій сентенції. 
Так, за даними НБУ [12], загальні активи банківських установ збільшились за 20002019 рр. 50,8 до 2953,9 млрд грн, тобто у 58 разів. Їхня частка у ВВП країни зросла відповідно з 24,9 до 74 \%. Звідси випливає висновок, що проблема полягає не у недостатності фінансових ресурсів, а їх розподілі.

Одним із можливих заходів спрямування фінансових ресурсів на потреби інвестиційного процесу може стати обмеження з боку НБУ (дохідності і обсягів) кредитування населення. Порівняно з процентною ставкою за кредитами нефінансовим корпораціям ставка домогосподарствам має бути на 1,5-2,0 \% нижчою. Щодо обмеження на суму кредитів домогосподарствам, то експертами запропоновано встановити максимальний обсяг споживчого кредиту у 10 тис. грн, на придбання, будівництво та реконструкцію нерухомості - 150 тис. грн, а інші кредити - 50 тис. грн. На нашу думку, зазначене не сприятиме зниженню попиту на нерухомість, іноземні товари та послуги.

Загалом модель організації фінансової системи в Україні подібна до моделі фінансування економічних процесів інших країн, що розвиваються. Істотне переважання депозитних посередників у структурі національного фінансового сектору економіки було визначено: 1) посиленням інсайдерської структури власності, де переважають великі корпоративні власники. При цьому мажоритарні акціонери віддають перевагу банківським кредитам і не цікавляться акціонуванням і розмиванням власності; 2) більш ефективним регулюванням банківської діяльності порівняно з іншими фінансовими установами; 3) зосередження торговельної активності на ринку цінних паперів на обмеженій групі інструментів, зокрема боргових цінних паперах на противагу пайовим у вільному обігу; 4) недоступність ресурсів ринку цінних паперів для малого і середнього бізнесу. Сьогодні економіку України можна виразити такою схемою високого відсотка - високого ризику - низької рентабельності, а має бути низьким відсотком - низьким ризиком - високою рентабельністю; 5) доступністю і зрозумілістю для клієнтів банківських послуг, коли небанківські тільки набувають розвитку; 6) низькою фінансовою грамотністю та низьким рівнем доходів на душу населення.

Щодо недепозитних фінансових корпорацій, то в дослідженнях фахівців Світового банку зазначено, що вони не досягнуть реальної ваги й великого обсягу без побудови ефективної та міцної банківської системи. В Україні цього поки що не відбувається, тож, саме розвиток банківської справи визначається як пріоритетний напрям, а іншої виправданої та надійної моделі розвитку фінансового сектору просто немає [10]. На нашу думку, зосередження уваги на банківських установах нівелює проблеми розвитку ринку цінних паперів, де ті самі банки є основними гравцями. Високотехнологічні виробництва та великі вітчизняні компанії потребують емісійного фінансування, а іноземні компанії та інституційні інвестори потребують ефективного та активного ринку цінних паперів. Учасники останнього орієнтуються на ринкові індикатори, а ринок $є$ основою перерозподілу фінансових ресурсів у межах довгострокових стратегій і концепцій.

Група українських учених також дотримується позиції, що банківські установи мають продовжувати бути базою формування та розвитку фінансового ринку, оскільки «мають більше можливостей, ніж інші фінансові інституції впливати на економічне зростання країни, принаймні до того часу, поки не почне ефективно працювати фондовий ринок... Саме банкоцентрична модель фінансового ринку більшою мірою, ніж модель 3 домінуванням ринку цінних паперів дозволить пом'якшити актуальну для України проблему «принципал-агент», забезпечити доступ до зовнішнього фінансування широкому колу вітчизняних підприємців, збільшити швидкість структурних трансформацій в економіці» [8, с. 16]. Варто акцентувати на тому, що не тільки банки визначають економічний розвиток країни, але й недепозитні фінансові посередники як інституційні інвестори, які формують і забезпечують розвиток ринку цінних паперів. 
ФІНАНСОВІ РЕСУРСИ: ПРОБЛЕМИ ФОРМУВАННЯ ТА ВИКОРИСТАННЯ

У країні триває ситуація, коли на ринку пропонується обмежена кількість прийнятних для вкладання активів страховиків, інвестиційних і пенсійних фондів фінансових інструментів. Основні інвестори в цінні папери - це банки, а решта фінансових посередників тримає свої активи переважно на банківських депозитах. Знижуються можливості для економіки в частині використання переваг цих установ, як-от підвищення якості управління компаніями реального сектору, що їх могли б фінансувати пенсійні та інвестиційні фонди, повніше та краще страхування життя і ризиків, розширення обсягів кредитів суб'єктам малого бізнесу від кредитних спілок, а також активізація інвестиційних процесів через операції лізингодавців тощо.

Утім прогнозується певний відплив активів банківської системи на фінансовий ринок, зокрема ринок цінних паперів. 3 одного боку, це розміщення не знижує ризиків для домогосподарств, які заощаджують гривню і конвертують грошові ресурси у валютні цінності, з іншого - проблеми банківської ліквідності не можуть не стимулювати відпливу коштів домогосподарств на фінансовий ринок. Проте контроль за залученням і використанням грошових ресурсів домогосподарств професійними учасниками ринку цінних паперів залишається недостатнім, на відміну від організованої банківської системи захисту інтересів вкладників. Під час світової фінансової кризи 2007-2008 рр. українські регулятори зосередила зусилля виключно на рятуванні банківської системи i залишили напризволяще більшість недепозитних фінансових посередників, послугами яких користувались і користуються мільйони громадян. В інших країнах антикризовими кроками на початку були заходи із рекапіталізації фінансових корпорацій, а в Україні ними стали заборони на дострокове повернення депозитів, що підірвало у підсумку ще більше довіру до фінансових установ. Подальші антикризові кроки полягали у виділенні фінансової допомоги окремим банкам для підтримання їхньої стабільної діяльності. Українська асоціація інвестиційного бізнесу неодноразово зверталась до Національної комісії з цінних паперів і фондового ринку, Національної комісії, що здійснює державне регулювання у сфері ринків фінансових послуг, і Національного банку України щодо пошуку механізмів впливу на банківські установи. Деякі страхові компанії та фонди подавали судові позови на останні, проте розгляд цих позовів виявився тривалим внаслідок неефективності судової системи в державі. Вважається, що зняти напругу між фінансовими інститутами може виділення цільового рефінансування банків під повернення коштів (депозитів) різних груп інституційних інвесторів.

При цьому важливо поєднувати процеси розвитку фінансового і реального сектору за допомогою:

- застосування для фінансування інноваційних проєктів преференцій і пільг, величину яких можна розрахувати на основі прогнозу збільшення надходжень податків від отримувачів фінансових ресурсів із завершенням реалізації цих проєктів; запровадження системи ефективних санкцій за порушення умов користування наданими ресурсами;

- державного гарантування банківських позичок через створення Національного фонду гарантій для інвестиційно-інноваційних проєктів;

- рефінансування банківських установ НБУ за жорсткого контролю його цільового спрямування; створення системи цільового рефінансування за зниженою ставкою під участь банків у реалізації схвалених державою інвестиційно-інноваційних програм і проєктів;

- стимулювання входження фінансових установ в інвестиційні проєкти не тільки як кредиторів, а і співвласників, співінвесторів тощо;

- обмеження банківської маржі на кредитно-депозитних операціях, наприклад, введення спеціального податку на чистий процентний дохід вище певного рівня; 
- активного розвитку приватно-державного партнерства (зокрема кластерних об'єднань), адже остання фінансова криза зумовлює еволюцію соціальної держави в державу партнерську;

- запровадження Стандарту процесу інноваційного кредитування, що являє собою сукупність вимог, що відображають стан кращої банківської практики в галузі інвестиційного кредитування на інноваційні цілі; зацікавленими особами будуть банківські установи, позичальники, власники ресурсів, державні органи і СРО; складовими - продуктова, технологічна, організаційна, управлінська, інформаційна, програмно-технічна, кадрова, технічно-майнова та клієнтська;

- обмеження частки ринку для фінансових установ 3 державною участю 3 метою розвитку конкурентного середовища на ринку капіталу;

- усунення інституційних бар'єрів для дистанційного фінансового обслуговування;

- визначення механізму реалізації застави, особливо житлового фонду за іпотечними кредитами.

Висновки та пропозиції. Загалом закономірності розвитку фінансового сектору i ринку цінних паперів дозволяють визначити їх основні тенденції, що проявляються в: 1) універсалізації фінансової та страхової діяльності та фінансового сектору зокрема; 2) формуванні інформаційної прозорості й подолання інформаційної асиметрії, що забезпечується єдиними методиками виміру; 3) посиленні конкуренції між окремими суб' єктами ринку цінних паперів і фінансового сектору зі створенням фінансових супермаркетів; 4) монополізації ринків цінних паперів, що полягатиме в концентрації фінансових операцій в окремих центрах; 5) розширенні кола користувачів послугами виробників цих послуг через електронні мережі й Інтернет; 6) формуванні нової глобальної архітектури ринку цінних паперів і фінансового сектору через пошук нового консенсусу у міжнародній політиці [7].

Нині найактуальнішим завданням залишається завдання розробки практичних рекомендацій з подальшого інституційного розвитку ринку цінних паперів і сектору фінансових корпорацій (фінансового сектору) в Україні. Це спричинене і тим, що глобалізація і фінансіалізація економічних процесів, зростання відкритості економіки істотно підвищили вразливість внутрішньої фінансової та страхової діяльності від негараздів економічного розвитку. До викликаної невпорядкованістю інституційного середовища ендогенної економічної стагнації додаються негативні наслідки втрати конкурентоспроможності економіки через тривале посилення негативного впливу інституційних змін та аномалій.

\section{Список використаних джерел}

1. Активізація інвестиційного процесу в Україні: монографія / Т. В. Майорова та ін. ; за наук. ред. М. І. Диби, Т. В. Майорової. Київ : КНЕУ, 2012. 143 с.

2. Боголепов М. И. Биржи и банки: в 2 т. / [под ред. проф. Л. Н. Яснопольского]. Киев : Изд-во Банковской Энциклопедии, 1917. Т. 2: Биржа. История и современная организация фондових бирж на Западе и в России. 382 с.

3. Гай-Нижник П. Приватні банківські та кредитні установи в Україні 1917-1918 років. Biсник Національного банку України. 2009. № 6. С. 35-39.

4. Державна служба статистики України. URL http://www.ukrstat.gov.ua.

5. Коваленко Ю. М. Етапи інституційних трансформацій у банківській системі на теренах України. Наукові записки Національного університету «Острозька академія». Серія: "Економіка». 2015. Вип. 28. С. 119-124.

6. Коваленко Ю. М. Інституціалізація фінансового сектору економіки : монографія. Ірпінь, 2013. $608 \mathrm{c}$.

7. Коваленко Ю. Формування комплементарної моделі фінансового сектору економіки. Вісник Наџіонального банку України. 2012. № 7. С. 42-47. 
ФІНАНСОВІ РЕСУРСИ: ПРОБЛЕМИ ФОРМУВАННЯ ТА ВИКОРИСТАННЯ

8. Козьменко С., Васильєва Т., Леонов С. Використання рядів Фур'є для формалізації структури фінансового ринку України. Економіст. 2011. № 2. С. 15-19.

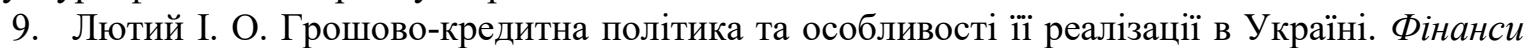
України. 2000. № 1. С. 20-24.

10. Мошенський С. 3. Історія ринку цінних паперів України у складі російської імперії (друга половина XIX - початок XX ст.). Вісник ЖДТУ. Серія «Економічні науки». 2011. № 4(58). C. 354-363.

11. Національна комісія 3 цінних паперів та фондового ринку. URL: http://www.nssmc.gov.ua.

12. Національний банк України. URL: https://bank.gov.ua.

13. Олейник А. Институциональная экономика : [учеб. пособие]. Москва : ИНФРА-М, $2002.416 \mathrm{c}$.

14. Цуканова Н. М. Професіоналам фондового ринку невигідно обманювати клієнтів. Фінанси Украӥни. 1996. № 10. С. 87-92.

15. Kindleberger C. P. A Financial History of Western Europe. New York : Oxford University Press, $1993.524 \mathrm{p}$.

16. Lin J. Y., Sun X., Jiang Y. Toward a Theory of Optimal Financial Structure. World Bank Policy Research Working Paper Series. 2009. № 5038. Pp. 1-29.

17. The World Bank. URL: https://www.worldbank.org.

\section{References}

1. Mayorova, T. V., Dyba, M. I., Onyshko, S. V. and others (2012). Aktyvizatsiia investytsiinoho protsesu v Ukraini [Activation of the investment process in Ukraine]. KNEU.

2. Boholepov, M. Y. (2017). Byrzhy y banky [Exchanges and banks]. (Vol. 2). Izd-vo Bankovskoi Entsyklopedii.

3. Hai-Nyzhnyk, P. (2009). Pryvatni bankivski ta kredytni ustanovy v Ukraini 1917-1918 rokiv [Private banking and credit institutions in Ukraine in 1917-1918]. Visnyk Natsionalnoho banku Ukrainy - Bulletin of the National Bank of Ukraine, 6, pp. 35-39.

4. Derzhavna sluzhba statystyky Ukrainy [State Statistics Service of Ukraine]. (n.d.). http://www.ukrstat.gov.ua.

5. Kovalenko, Yu. M. (2015). Etapy instytutsiinykh transformatsii u bankivskii systemi na terenakh Ukrainy [Stages of institutional transformations in the banking system in Ukraine]. Naukovi zapysky Natsionalnoho universytetu "Ostrozka akademiia". Seriia "Ekonomika" - Scientific notes of the National University "Ostroh Academy”. Serie: Economics, 28, pp. 119-124.

6. Kovalenko, Yu. M. (2013). Instytutsializatsiia finansovoho sektoru ekonomiky [Institutionalization of the financial sector of the economy]. National University of the State Tax Service of Ukraine.

7. Kovalenko, Yu. (2012). Formuvannia komplementarnoi modeli finansovoho sektoru ekonomiky [Formation of the complementary model of the financial sector of the economy]. Visnyk Natsionalnoho banku Ukrainy - Visnyk of the National Bank of Ukraine, 7, pp. 42-47.

8. Kozmenko, S., Vasylieva, T., Leonov, S. (2011). Vykorystannia riadiv Furie dlia formalizatsii struktury finansovoho rynku Ukrainy [The use of Fourier series to formalize the structure of the financial market of Ukraine]. Ekonomist-Economist, 2, pp. 15-19.

9. Liutyi, I. O. (2000). Hroshovo-kredytna polityka ta osoblyvosti yii realizatsii v Ukraini [Monetary policy and features of its implementation in Ukraine]. Finansy Ukrainy - Finance of Ukraine, 1, pp. 20-24.

10. Moshenskyi, S. Z. (2011). Istoriia rynku tsinnykh paperiv Ukrainy u skladi rosiiskoi imperii (druha polovyna XIX - pochatok XX st.) [History of the securities market of Ukraine as part of the Russian Empire (second half of the nineteenth - early twentieth century]. Visnyk ZhDTU - Bulletin of ZhSTU, 4 (58), pp. 354-363.

11. Natsionalna komisiia $\mathrm{z}$ tsinnykh paperiv ta fondovoho rynku [National Commission on Securities and Stock Market]. (n.d.). http://www.nssmc.gov.ua.

12. Natsionalnyi bank Ukrainy [National Bank of Ukraine]. (n.d.). https://bank.gov.ua.

13. Oleinyk, A. (2002). Instytutsyonalnaia ekonomyka [Institutional economics]. INFRA-M. 
14. Tsukanova, N. M. (1996) Profesionalam fondovoho rynku nevyhidno obmaniuvaty kliientiv [It is unprofitable for stock market professionals to deceive clients]. Finansy Ukrainy - Finance of Ukraine, 10, pp. 87-92.

15. Kindleberger, C. P. (1993). A Financial History of Western Europe. Oxford University Press.

16. Lin, J. Y., Sun, X., Jiang, Y. (2009). Toward a Theory of Optimal Financial Structure. World Bank Policy Research Working Paper Series, 5038, pp. 1-29.

17. The World Bank. (n.d.). https://www.worldbank.org.

Коваленко Юлія Михайлівна - доктор економічних наук, професор, професор кафедри фінансових ринків, Університет державної фіскальної служби України (вул. Університетська, 31, м. Ірпінь, 08201, Україна).

Коваленко Юлия Михайловна - доктор экономических наук, профессор, профессор кафедры финансовых рынков, Университет государственной фискальной службы Украины (ул. Университетская, 31, г. Ирпень, 08201, Украина).

Kovalenko Yuliia - Doctor of Economics, Professor, Professor of Financial Markets Department, University of the State Fiscal Service of Ukraine (31 Universitetska Str., 08201 Irpin, Ukraine).

E-mail: kovalenko0202@ukr.net

ORCID: htpp://orcid.org./0000-0002-5678-3185

ResearcherID: H-4742-2018

Коваль Іван Анатолійович - аспірант, Університет державної фіскальної служби України (вул. Університетська, 31, м. Ірпінь, 08201, Україна).

Коваль Иван Анатолиевич - аспирант, Университет государственной фискальной службы Украины (ул. Университетская, 31, г. Ирпень, 08201, Украина).

Koval Ivan - PhD student, University of State Fiscal Service of Ukraine (31 Universitetska Str., 08201 Irpin, Ukraine).

E-mail: 7ivankoval@gmail.com

Близненко Єлизавета Олександрівна - здобувачка вищої освіти, Університет державної фіскальної служби України (вул. Університетська, 31, м. Ірпінь, 08201, Україна).

Близненко Елизавета Александровна - соискательница высшего образования, Университет государственной фискальной службы Украины (ул. Университетская, 31, г. Ирпень, 08201, Украина).

Blyznenko Yelyzaveta - Applicant for higher education, University of State Fiscal Service of Ukraine

(31 Universitetska Str., 08201 Irpin, Ukraine).

E-mail: yelizavetabliznenko@gmail.com

Коваленко Ю., Коваль І., Близненко $Є$. Вплив моделі сектору фінансових корпорацій і ринку цінних паперів на інвестиційні процеси в Україні. Проблеми і перспективи економіки та управління. 2020. № 2 (22). С. 117-130. 